\title{
48
}

\section{Enabling Marginalised Voices to Be Heard: The Challenge to Law Reform Bodies}

\author{
Liz Curran
}

\section{Introduction}

Often the processes for law reform enable only certain voices to be heard, facilitating involvement by the most well-resourced pressure groups or lobbyists, the articulate and well educated. Yet laws affect us all. For some people, especially in lower socioeconomic contexts, government policies and laws affect every element of life from income security to the habitable condition of public housing to access to health services and pensions. People with poor literacy and numeracy have unequal access to opportunity and rarely have a voice or a way to provide feedback. The current structures for seeking input from these groups into law reform are problematic. They assume knowledge of the processes and of the law and legal rights, and the confidence to take action which is often absent for these groups. ${ }^{2}$

1 Senior Lecturer, The Australian National University, Legal Workshop.

2 Christine Coumarelos et al, Access to Justice and Legal Needs: Legal Australia Wide Survey: Legal Need in Australia (Law and Justice Foundation of New South Wales, 2012); Liz Curran and Maryanne Noone, 'Access to Justice: A New Approach Using Human Rights Standards' (2008) 15(3) International Journal of the Legal Profession, 195. 
As a result, laws that deeply affect these communities are made in isolation with little input from those with direct experience. It is left to community agencies and peak bodies to try to relay experiences of their clients. This second-hand input is valuable, but does not give voice to the affected communities and their direct lived experience. If law reform is disconnected from lived experience, it is consequently blunt and less effective.

This chapter highlights why the current approach to law reform is problematic in the context of participatory democracy. It explores the obligations of lawyers and identifies innovative ways that law reform can occur beyond traditional avenues for law reform. It presents three case studies which have had a significant impact in changing laws, regulation and behaviours and demonstrate different law reform processes that can be timely and responsive to the immediate need of individuals. Some suggestions for inclusive law reform are also offered.

\section{The Role of Lawyers in Law Reform}

Lawyers have an obligation to uphold the rule of law and maintain the integrity of the legal system.

The following principles which underpin the rule of law $^{3}$ are relevant to this discussion:

- The law is made by representatives of the people in an open and transparent way;

- The law and its administration is subject to open and free criticism by the people ...;

- The law is capable of being known to everyone, so that everyone can comply.

As noted, sections of the community often do not know the law, or know where to turn, nor do they have the confidence to action their rights. ${ }^{4}$ They seldom have resources to enable their voices to be heard as to how the laws that affect them are shaped. As Davis notes, this sits in a context of often professional lobbyists and well-resourced groups

3 See Rule of Law Institute of Australia, Principles, www.ruleoflaw.org.au/principles/.

4 Curran and Noone, above n 2. 
that provide input. ${ }^{5}$ This scenario has implications for the rule of law. Furthermore, executive governments in Australia have extended their own powers ${ }^{6}$ limiting court review. This practice has affected human rights cases by limiting court scrutiny of executive action. ${ }^{7}$

Under the Australian Solicitor's Conduct Rules (Vic, NSW) rr 3 and 4, lawyers have duties to the administration of justice. ${ }^{8}$ Accordingly, legal professionals have a role in identifying systemic problems because of their explicit obligations to ensure confidence in and integrity of the legal system. Being a lawyer is not limited just to the delivery of legal services as part of an industry. Lawyers as officers of the court have a deeper ethical obligation to identify and respond to systemic problems that impede confidence in the legal system and undermine its integrity. The advocacy by lawyers for clients through law reform and campaigns for change to policy administration ${ }^{9}$ are core to the lawyers' ethical duties where laws are unjust and unfair.

5 Ian Davis, 'Targeted Consultations' in Brian Opeskin and David Weisbrot (eds), The Promise of Law Reform (The Federation Press, 2005) Ch 10, 148-59, 154.

6 See ABC Radio National, 'Gillian Triggs Criticises "Executive Overreach" in Defiant Speech', $A M$, 6 June 2015 (Simon Lauder), www.abc.net.au/am/content/2015/s4250111.htm.

7 See Children, Youth and Families Amendment (Permanent Care and Other Matters) Act (2014) (Vic); Office of the Public Advocate, 'Legal and Child Welfare Groups Call for Reinstatement of Child Protection Powers for Children's Court' (28 February 2017) www.publicadvocate.vic.gov.au/ childrens-matters-media-release; Michael Chaaya, 'Proposed Changes to the Review of Migration Decisions: Sensible Reform Agenda or Political Expediency?'(1996) 19(4) Sydney Law Review 547.

8 See Frederick Ellison on the obligations of legal professionals to seek the social good, in Michael Davis and Frederick A Ellison (eds), Ethics and the Legal Profession (Prometheus Books, 1986) 18; Simon Longstaff, The Lawyer's Duty to the Community (The Ethics Centre, 1 March 1995), www. ethics.org.au/on-ethics/our-articles/before-2014/the-lawyers-duty-to-the-community. Former Chief Justice the Hon Murray Gleeson has also noted the obligation of the legal professions to ensure the public welfare and maintain confidence in the legal system - see Murray Gleeson, Are the Professions Worth Keeping? (Speech delivered at the Greek-Australian International Legal and Medical Conference, 31 May 1999), www.hcourt.gov.au/assets/publications/speeches/former-justices/ gleesoncj/cj_areprofe.htm; Murray Gleeson, Public Confidence in the Courts (Speech delivered at the National Judicial College of Australia, Canberra, 9 February 2007) 6-7, www.hcourt.gov.au/ assets/publications/speeches/former-justices/gleesoncj/cj_9feb07.pdf; Carl T Bogus, 'The Death of an Honourable Profession' (1996) 71(4) Indiana Law Journal 911.

9 Liz Curran, 'Attorney General George Brandis Set to Silence CLCs', The Saturday Paper (online), 14 June 2014, www.thesaturdaypaper.com.au/opinion/topic/2014/06/14/attorney-general-georgebrandis-set-silence-clcs/1402668000. 


\section{Why Evidence- and Practice-Based Research Are Critical for Good Law Reform}

Evidence- and practice-based experience and research that are linked to and not remote from day-to-day experience of laws can inform effectiveness, efficiency and positive outcomes. In 2007 the author wrote '[i]f governments of any political persuasion want to remain connected with the public and stay in power, they need to listen to their public. On many occasions, politicians claim to be connected to their communities. Often in reality, this is not the case'. ${ }^{10}$

Effective service programs (or laws that have been evaluated as effective) are often under-resourced or disbanded by government without empirical basis. The Productivity Commission made this point and called for research into this situation to inform government policy in Recommendation 24. ${ }^{11}$

The author further noted in 2007, 'The process of law reform is very slow to reap results as it often involves a sustained and persistent effort to raise awareness and change often entrenched cultures'. ${ }^{12}$ At that time the author struggled to find literature related to the process of law reform that focused on engaging with public experience. Then, in 2013, the author was again commissioned to examine seven law reform projects. ${ }^{13}$ Since the author's report in 2007, the conduct of law reform had changed, and was more creative, strategic and responsive to community, and less reactive.

The author's 2013 study revealed multiple strategies to overcome problems with people's experience of the law. The author was able to identify successful and impactful law reform initiatives of community legal centres (CLCs) (often conducted in collaboration with the people affected or other agencies). The processes used showed a strategic and

10 Liz Curran, Making the Legal System More Responsive to Community: A Report on the Impact of Victorian Community Legal Centre (CLC) Law Reform Initiatives, 2007, 4.

11 Productivity Commission, Commission Inquiry into Access to Justice Arrangements Report: Volume 1, Inquiry Report 72, 2014, 37, 43, 75-76.

12 Curran, above $n 9$.

13 See Liz Curran, Solving Problems - A Strategic Approach: Examples, Processes \& Strategies (Legal Workshop, The Australian National University College of Law, 13 May 2013), law.anu.edu.au/ sites/all/files/legalworkshop/final_report_solving_legal_problems_curran_calc_13_march_2013.pdf. 
multipronged approach to law reform using innovative approaches that directly engaged client experiences of the impact of the law and developed solutions to problems. ${ }^{14}$ Some are discussed below.

\section{Case Studies}

The following two case studies, 'National Bulk Debt Negotiation' and the 'Do Not Knock Sticker', were initiated by CLCs. A third case study is about direct community advocacy to a Parliamentary Inquiry. All of these case studies demonstrate ways lawyers can have a more direct role in empowering communities with the skills they might need to make arguments (something lawyers consider as part of their own professional toolkit) and enable community members to present their case first-hand to lawmakers.

\section{A. Case study one: Bulk debt negotiation}

The National Bulk Debt Project (the Project) which is still ongoing, aims to protect the income of those experiencing long-term financial hardship. It has not only led to a decision by creditors to desist in pursuing loans against the most vulnerable or disadvantaged but to changes in practice, codes of conduct and hardship provisions.

The project used unconventional approaches to bring about law reform and changes in predatory and poor practice. ${ }^{15}$ It aims to assist judgmentproof debtors struggling to repay. 'Judgment-proof' means there is no real likelihood that debtors can pay, that is, because they need all their income just to pay for food, rent and utilities or, as in Victoria, they have legislative protection from being sued. Instead of negotiations taking place for each client separately (which takes time and resources), they were bundled together into a 'bulk negotiation'. All cases involved clients on a low income. In the author's report of 2013, the examination of the project noted that many clients had multiple debts. Most clients experienced disadvantage including mental illness, disability, ill health or were full-time carers. Cases were collected en masse by financial counsellors and CLC

14 Ibid. 8.

15 A project of the West Heidelberg Community Legal Service, the Victoria Law Foundation, NSW and Victoria Legal Aid and Footscray Community Legal Service. The author discloses that she was Director of the West Heidelberg Community Legal Service at that time and secured the project's initial funding. 
lawyers and the clients' circumstances were documented by a volunteer and taken in bulk to each bank by the project lawyer. The project has since been extended to other industries. In many instances, the client either did not owe the debt in the first place, proceedings were prohibited by law or it was unrealistic to pursue them due to their personal circumstances (e.g. cancer or disability), which served to highlight problems in debt collection practice. Few of the complainants previously could have actioned their legal rights due to a lack of knowledge, resources or access to legal assistance on an individual case-by-case basis.

\section{Impact}

This project has made the banks see that their pursuit is harmful and often costly and inefficient. The debts taken in bulk have avoided costly individual court processes, poor recovery, harmful practices and waste of corporate resources.

The author's 2013 report revealed that the project has directly assisted over 2,500 debtors and negotiated waiver or closure of debts worth more than $\$ 15$ million. ${ }^{16}$ Updated on 12 April 2016, additional impacts of the project include:

- 70 per cent of debts were waived.

- A National Hardship Register introduced in January 2014 is directly traceable to the work of the project.

- Criteria and processes developed via bulk debt negotiations have been specifically incorporated into some of the major banks' business practices.

- The Code of Banking Practice has been updated with minimum standards for signatories. ${ }^{17}$

The project in this case study has led to the reform of banking practices. It has saved money, not just for the banks in wasted processes, but also in reduced court proceedings (previously undertaken as individual matters in courts on a case-by-case basis). It has also reduced stress and anxiety

16 Curran, above n 13, 26-34; Denis Nelthorpe and Kate Digney, The Bulk Negotiation Project: Client Profiles and Client Outcomes (West Heidelberg Community Legal Service and Victoria Law Foundation, 2011) 3.

17 J Holland, Negotiating Bulk Debt: Outcomes from the Bulk Debt Negotiation Project (unpublished report for Victoria Legal Aid, West Heidelberg Community Legal Service, Legal Aid NSW, Good Shepherd Australia \& New Zealand, 2016). The author thanks Denis Nelthorpe for sharing this report. 
for those with debts. Moreover, it has revealed many debts were not being lawfully pursued, giving rise to other systemic issues for the regulators. Poor laws affect lives; they can do harm, cause stress and lead to poor health. ${ }^{18}$

\section{B. Case study two: 'Do Not Knock' becomes law of trespass}

The Consumer Action Law Centre (CALC) in Melbourne was receiving complaints about door-to-door sales including high-pressure techniques to get people to sign contracts; misleading and deceptive conduct; faulty goods and services; the targeting of vulnerable groups; and the use of fraudulent contracts and conduct.

A novel and practical sticker affixed to the front door of a person's home saying 'Do Not Knock' served to deflect aggressive predatory sales practices (which targeted public housing estates with concentrations of new arrivals, elderly and people with a disability and poor literacy skills) while leading to a change in precedent. Law reform was achieved with a community awareness campaign; a sticker to protect people day-to-day; the compilation of complaints and provision of data to the regulator; media exposure; collaboration between council, the regulator and community agencies, legal and non-legal; and court action.

\section{Impact}

The sticker is used on doorways across Australia and is distributed by CALC, local councils and governments.

CALC collected complaints from consumers about continued 'door knocking' despite having the sticker on their door. These complaints were logged in bulk with the Australian Competition and Consumer Commission (ACCC). The ACCC then lodged a case in the Federal Court against a utility company. The court ruled that ignoring a sticker risks

18 Pascoe Pleasence, Nigel J Balmer and Alexy Buck, 'The Health Cost of Civil-Law Problems: Further Evidence of Links between Civil-law Problems and Morbidity, and the Consequential Use of Health Services' (2008) 5(2) Journal of Empirical Legal Studies 351. 
a fine of $\$ 50,000 .{ }^{19}$ The case before a single judge of the Federal Court was upheld on appeal. If the sticker is ignored, it constitutes trespass. Changes have also been made to industry codes.

This case study goes to show how a creative idea such as a 'Do Not Knock' sticker can have a significant impact in changing laws. The case illustrates how clients can be included and empowered to participate directly in law reform through a trusted intermediary (in this case CALC). It involved a collaboration of financial counsellors and social workers alongside affected clients. Further details about the approaches and processes are available in the 2013 report. $^{20}$

\section{Case study three: Enabling community voice}

Community members in a public housing Residents' Group (RG) in West Heidelberg (one of the poorest locations in Australia) were empowered to make their own submission. They had consistently reported poor housing for over a decade with no response.

The Victorian Government called a Parliamentary Inquiry into Public Housing in Victoria. The inquiry was called with a very limited lead-time at Christmas. The author (then Director of the West Heidelberg Legal Service) saw an inquiry advertisement and brought it to the residents' attention. The residents wanted to participate in an inquiry but had no idea how or what to do. They felt no one would listen to them. A plan of action and training was developed identifying what skills would be needed to participate in the inquiry. Enabling RG participation involved intensive sequential building-block training that was responsive to needs and gaps in skills, as very few members of the RG knew anything about decision-makers and processes. Many were fearful of departmental reprisals and so systems were developed to protect community members such as using numbers rather than names in the Focus Groups residents conducted with public housing residents. This underlines why people feel discouraged from participation in law reform processes.

19 Australian Competition and Consumer Commission v Neighbourhood Energy Pty Ltd [2012] FCA 1357.

20 Curran, above n 13, 29-34. 
These Focus Groups were recorded and transcribed by a pro bono law firm and formed into a written submission. The RG were called to 'give evidence' before the Parliamentary Inquiry. At first the parliamentarians directed questions to the author who had to firmly defer to the RG. Once the parliamentarians listened to the RG, the often brutal reality of life on a public housing estate led the parliamentarians to conclude it was 'the most powerful and compelling submission' and later adopted some recommendations of the RG. One politician noted at the hearing it was 'a most significant moment in democratic participation'.

\section{Suggestions for Inclusive Law Reform}

The author recognises that in a context of limited resources and funding for law reform bodies ${ }^{21}$ it is hard to think about non-traditional approaches to law reform. The ALRC, ${ }^{22}$ Victorian Law Reform Commission ${ }^{23}$ and other bodies have tried to increase public participation. ${ }^{24}$ Many of these processes rely on computer access, which is effectively a form of social exclusion for those without internet access or computer literacy. Community agencies are also under significant resource constraints, as noted by the Productivity Commission (PC) in its Final Report on Access to Justice Arrangements. ${ }^{25}$ The author's 2013 report $^{26}$ shows that this has not prevented innovations in law reform practice occurring. Many initiatives derive from a need to find better ways of responding due to a lack of capacity for one-on-one cases, identifying the systemic causes in multiple cases and working collectively to address problems at the source.

21 Michael Kirby, Plenary Address delivered at the Inaugural National Law Reform Conference, Canberra, 14 April 2016.

22 See Australian Law Reform Commission, Talk to Us (24 September 2015), www.alrc.gov.au/ talk-us.

23 See Victorian Law Reform Commission, About Community Law Reform (26 May 2016), www. lawreform.vic.gov.au/all-projects/about-community-law-reform.

24 Ian Davis, 'Targeted Consultations' and Roslyn Atkinson, 'Law Reform and Community Participation' in Brian Opeskin and David Weisbrot (eds), The Promise of Law Reform (The Federation Press, 2005) Ch 10, 148-59; Ch 11, 160-74.

25 Productivity Commission, Commission Inquiry into Access to Justice Arrangements Report: Volume 2, Inquiry Report 72, 2014, 696-700.

26 Curran, above n 13. 
Law reform agencies and regulators can learn from these case studies. Scarce resources need not be an inhibitor. Initiatives can include:

- facilitated Focus Groups instead of written submissions where targeted participants are de-identified, enabled, and supported in a safe space (Case Study Three);

- submissions developed through community lunches and conversations with people directly affected by policies. These gatherings could be facilitated by community agency linkages to bring together affected communities;

- training and working with communities through their trusted intermediaries, be they 'peer-to-peer' learning or skilled-up, supported by legal and non-legal professionals, which the case studies above demonstrate can enable civil participation;

- anonymous input (for those who fear reprisals or are embarrassed or do not want public attention);

- advice telephone lines set up to help people navigate having their views heard through either direct support in making oral or written submissions;

- closer liaison with community groups and organisations about their trend identification of systemic issues (Case Studies One and Two);

- problem-solving of individual complaints by collective complaints (e.g. National Bulk Debt Negotiation).

\section{Conclusion}

The author has argued that it is possible for law reform processes to engage better with the people often marginalised by society who are deeply affected by laws and their administration through innovative approaches. ${ }^{27}$ Law Reform bodies with their expertise can bring about a reality check by facilitating connected and realistic, practical policy responses that capture and channel voices into evidence-based research.

27 Catholic Commission for Justice, Development and Peace, “"It's Not Easy Walkin' in There": Aboriginal Reconciliation: Towards Practical and Culturally Respectful Solutions (Catholic Commission for Justice, Development and Peace, 1999). 
There is a role for lawyers, consistent with their professional duties to the rule of law, to ensure confidence in and integrity of the legal system, and to empower and upskill communities. Lawyers have a significant role to play in demystifying the political and legislative processes and enabling participation and in advocacy and empowering communities to ensure the law protects them and is fair and just.

In its Final Report on Access to Justice Arrangements, ${ }^{28}$ the Productivity Commission stressed that there is a 'disconnect between legal need and government funding ${ }^{29}$ and a need for innovative holistic approaches to problem solving. ${ }^{30}$ It endorsed the systemic work done by agencies. ${ }^{31}$ This view contrasts notably with government actions actively discouraging such systemic work. ${ }^{32}$ The PC encourages regulators to respond to such systemic issues and be more proactive in stopping problems at their core and preventing additional costs. ${ }^{33}$

This view might be considered a 'call to action' to law reform bodies. Given the significant obstacles many people have to having their voices heard in law-making, the public is increasingly disengaged. If we truly inhabit a participatory democracy, we need to find ways for people who are often hindered by personal circumstances to have a direct voice. Arming community service agencies (so often stretched in terms of resources and demands of service delivery) with the ability to build capacity within communities to engage directly with law reform can lead to greater input and change. If this occurs, policy will be more relevant, responsive, timely, comprehensive and effective. This is needed at times of increasing worldwide public alienation from legislative and political systems.

28 Productivity Commission, Commission Inquiry into Access to Justice Arrangements Report: Overview, Inquiry Report 72, 2014, 28.

29 Ibid.

30 Productivity Commission, above n 11 (Vol 1), 171-176; n 21 (Vol 2), 713; Overview, above n 28, 43.

31 Productivity Commission, Overview, above n 28, 12, 11, 31; n 21 (Vol 2), 708-713.

32 See new $\mathrm{cl} 5$ inserted by federal government funding agreements with legal aid commissions and community legal centres. See also Curran, above $\mathrm{n} 9$.

33 Productivity Commission, Overview, above n 28, 30-31. 
This text is taken from New Directions for Law in Australia: Essays in Contemporary Law Reform, edited by Ron Levy, Molly O’Brien, Simon Rice, Pauline Ridge and Margaret Thornton, published 2017 by ANU Press, The Australian National University, Canberra, Australia. 